\title{
Measured and predicted temperatures in a grain processing building under heat treatment -1 . Temperature profiles during heat treatment
}

\author{
F. Jian ${ }^{1}$, P.G. Fields ${ }^{2}$, D.S. Jayas ${ }^{1 *}$, N.D.G. White ${ }^{2}$ and M. Loganathan ${ }^{1,3}$ \\ ${ }^{I}$ Department of Biosystems Engineering, University of Manitoba, Winnipeg, MB, R3T 5V6, Canada; \\ ${ }^{2}$ Agriculture and Agri-Food Canada, Cereal Research Centre, 195 Dafoe Road, Winnipeg, MB, R3T 2M9, Canada; and \\ ${ }^{3}$ Indian Institute of Crop Processing Technology, Ministry of Food Processing Industries, Government of India, \\ Pudukkottai Road, Thanjavur 613 005, India. \\ *Email: Digvir_jayas@umanitoba.ca
}

Jian, F., P.G. Fields, D.S. Jayas, N.D.G. White and M. Loganathan. 2012. Measured and predicted temperatures in a grain processing building under heat treatment - 1. Temperature profiles during heat treatment. Canadian Biosystems Engineering/Le génie des biosystèmes au Canada 54: 3.1-3.8. Heat treatment is an effective method of controlling pest insects in grain processing facilities. Temperatures inside a heat-treated flour-storage building and temperatures of wheat, oats, wheat flour, and oat flour in piles or tubes, $0.15 \mathrm{~m}$ high, on a concrete floor inside the building, were measured during a 20 -h time period of heat treatment. The room temperature at different locations had the same distribution pattern in the vertical direction despite the presence of circulating fans at different locations of the room. Temperature gradients in the vertical direction decreased with increasing height. The maximum and mean temperature gradients above the surface of the concrete floor, in the absence of grain, were $5.4^{\circ} \mathrm{C} / \mathrm{cm}$ and $3.6 \pm 0.0^{\circ} \mathrm{C} / \mathrm{cm}$; respectively. The room temperatures at higher locations varied less than those at lower locations. Moreover, after the surface grain temperature reached $97 \%$ of its maximum temperature, it was influenced by the local temperature and periphery configuration. Key words: Heat treatment, grain-processing building, temperature.

Le traitement thermique est une méthode efficace de lutte contre les insectes ravageurs dans les installations de transformation des céréales. Pendant un traitement thermique dans un entrepôt de farine, nous avons mesuré les températures ambiantes ainsi que celles du blé, de l'avoine, de farine de blé et de farine d'avoine, soit en tas ou en tubes de $0,15 \mathrm{~m}$ de hauteur, sur un plancher de béton à l'intérieur de l'entrepôt tout au long des 20 heures du traitement. Les températures ambiantes à divers endroits avaient la même distribution dans le sens vertical, malgré la présence de ventilateurs à différents endroits de la salle. Les gradients de température dans la direction verticale ont diminué avec la hauteur. Le maximum et la moyenne des gradients de température au-dessus de la surface du plancher de béton, sans grain, étaient de $5,4^{\circ} \mathrm{C} / \mathrm{cm}$ et $3,6 \pm 0,0^{\circ} \mathrm{C} / \mathrm{cm}$; respectivement. Les températures ambiantes aux endroits les plus élevés variaient moins que celles aux endroits moins élevés. De plus, après que la température du grain de surface ait atteint $97 \%$ de sa température maximale, elle a été influencée par la température locale et la configuration périphérique. Mots clés: traitement thermique, installations de transformation des céréales, température.

\section{INTRODUCTION}

Controlling stored-product insects by heating food processing and storage facilities to lethal temperatures is an old and effective technology (Dean 1911; Fields 1992; Beckett et al. 2007). This method was widely used at the turn of the 20th century, but was replaced with chemical fumigation because of its lower cost and ease of application. Methyl bromide, a space fumigant widely used for disinfestations of food processing facilities, was phased out in 2005 in developed countries. Heat treatment is one of the alternatives to replace methyl bromide (Fields and White 2001). Most modern grain processing buildings can withstand temperatures of $50^{\circ} \mathrm{C}$ to $60^{\circ} \mathrm{C}$ for extended periods of time (Imholte and Imholte-Tauscher 1999). However, caution should still be exercised, to prevent damage to heat-sensitive equipment.

During heat treatment, the entire facility, or portions of, is heated to between $50^{\circ} \mathrm{C}$ to $60^{\circ} \mathrm{C}$ for 24 to 36 hours (Imholte and Imholte-Tauscher 1999; Fields and White 2001). Stored-product insects are dead within $8 \mathrm{~h}$ at $50^{\circ} \mathrm{C}$ (Fields 1992; Mahroof et al. 2003a). Grain processing facilities are large complex structures. The 24 to $36 \mathrm{~h}$ time period at $50^{\circ} \mathrm{C}$ is required so that all the contents of the facility can reach $50^{\circ} \mathrm{C}$ and provide a sufficient length of time to kill all insects. It is also recommended that grain and grain products be removed from silos, equipment and floors before heat treatment (Imholte and ImholteTauscher 1999; Beckett et al. 2007). The reason for this extensive sanitation is that grain and grain products are good thermal insulators (Jian et al. 2009), thus providing refuge for insects from extreme temperatures. Cleaning and emptying the facility and equipment, which is done after the entire facility is shut down and before heat treatment is started, is time consuming and a challenge because the cleaning must be completed in a short time period. Flour mill owners want to maximize the duration that the facility is in operation. Therefore, it would be useful to determine the maximum amount of grain or grain products that can be 
left behind in equipment and on floors, and whose presence would still allow enough heat to penetrate the product and control insects.

Time-temperature relationships play an important role in effective heat treatment for insect management (Mahroof et al. 2003a; 2003b). Effectiveness of this heat treatment process is determined by maintaining an air temperature between 50 to $60^{\circ} \mathrm{C}$ inside the entire building. In two heat-treated buildings, Akdogan et al. (2005) found the maximum temperature varied substantially throughout the treated rooms. Under-heated areas, with temperature less than $50^{\circ} \mathrm{C}$, were detected on every floor. These underheated areas were mostly detected in corners or along walls. Therefore, it is a challenge to establish a heating system that will maintain a balanced distribution of heat on all floors (Akdogan et al. 2005) and, at the same time, avoid the risk of damage to heat-sensitive equipment.

Temperature prediction using a mathematical model is one of the methods guiding effective heat treatment to achieve an evenly balanced heat distribution, because of the following: 1) a mathematical model can also predict cold areas; 2) predicted temperature distribution can be used to design heat treatments and avoid over- and underheating; 3) redirecting heat from the predicted over-heated areas to cooler areas will facilitate homogeneous heating; and 4) this method can minimize energy and duration required for heat treatment. Verification and validation using measured heat treatment data are necessary procedures to develop a highly accurate mathematical model.

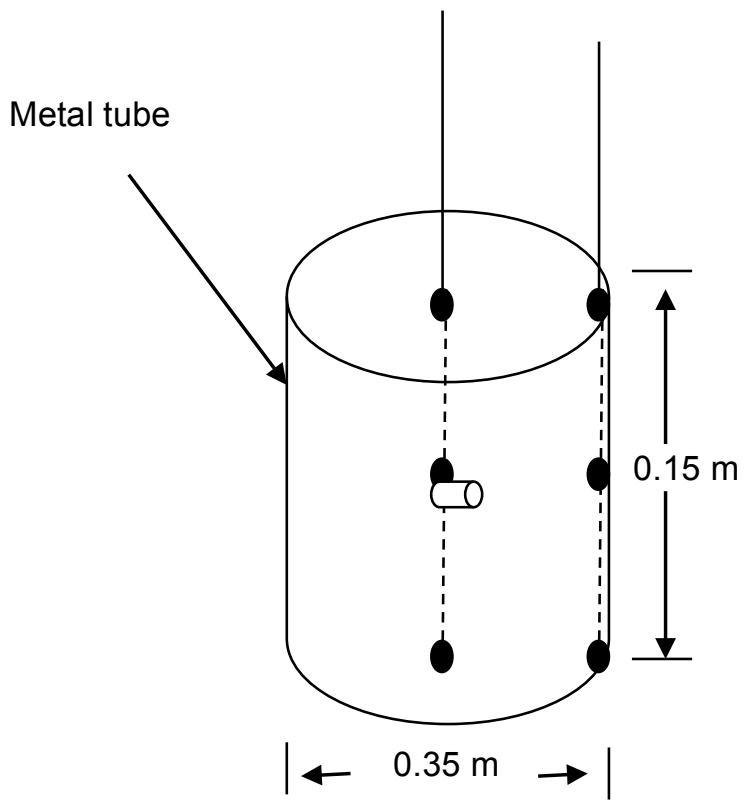

The aims of this study were to determine: 1) the room temperature distribution inside a flour mill storage building during heat treatment; 2) the temperatures of the concrete floor covered with different grain types; and 3) the temperature distribution of grain mass on the concrete floors. The measured data were used to verify and validate the developed mathematical models in Part II (Jian et al. 2012).

\section{MATERIALS AND METHODS}

\section{Grain and grain flour}

Hard red spring wheat seed (AC Barrie), unbleached wheat flour, oat seed of mixed varieties, and unbleached oat flour were used. Varieties of the grains were produced in Manitoba and Saskatchewan, Canada. Grain moisture content was determined using a standard oven-drying method by drying triplicate samples at $130^{\circ} \mathrm{C}$ for $19 \mathrm{~h}$ (ASABE 2009). The initial moisture contents of the wheat, oats, wheat flour, and oat flour were $12.8 \pm 0.2 \%$, $13.1 \pm 0.2 \%, 13.9 \pm 0.2 \%$, and $10.0 \pm 0.4 \%$, respectively.

\section{Insects}

The adults of Tribolium castaneum (Herbst) were prepared at room temperature in a laboratory at the Cereal Research Centre of Agriculture and Agri-Food Canada in Winnipeg, MB. Wheat flour or wheat $(10 \mathrm{~g}$ at about $12 \%$ moisture content, wet basis) mixed with brewer yeast (95:5 by weight) was loaded into vials $(0.03 \mathrm{~m}$ diameter and $0.05 \mathrm{~m}$ high). Vials were capped with $600 \mu \mathrm{m}$ wire mesh after 50 adults were introduced at the top of the flour. The vials with insects were shipped to the mill. During shipment, the adults experienced temperatures varying from $20^{\circ} \mathrm{C}$ to $25^{\circ} \mathrm{C}$.

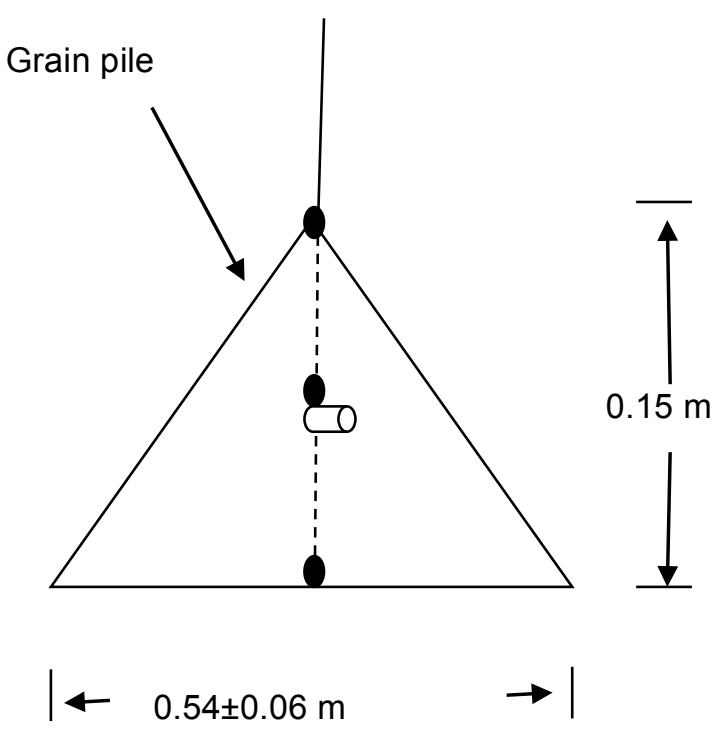

Fig.1. Side view of the grain tube and the grain pile. The black dots show the thermocouple locations inside the grain or flour, the lines indicate the wire of the thermocouples, and the small cylinders indicate the vial with $\mathbf{5 0}$ adult $T$. castaneum. 


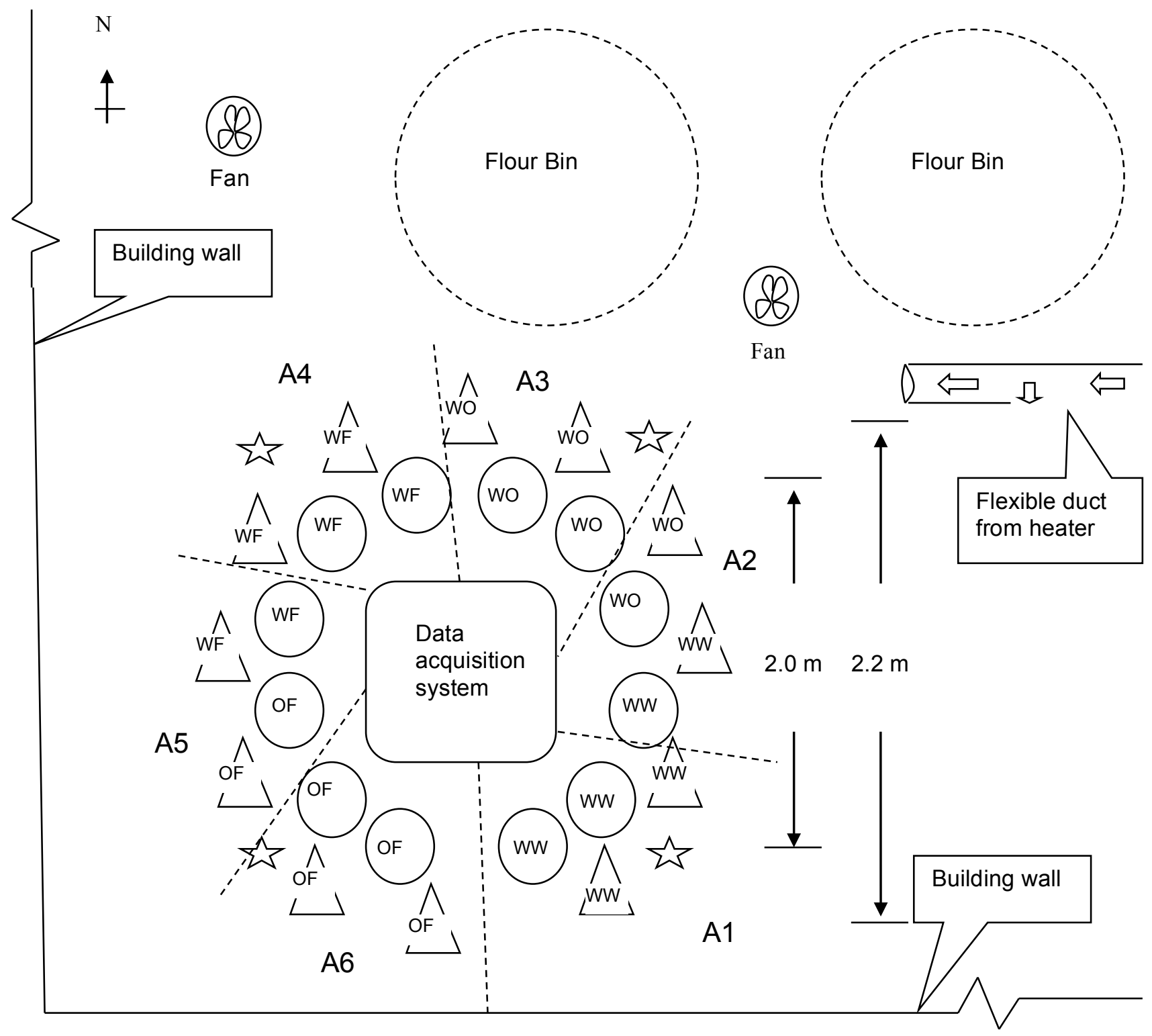

Fig. 2. Arrangement of tubes and piles of grain and flour on the ground floor of a building undergoing heat treatment. The stars indicate the locations of the room temperature thermocouples. $W W=$ whole wheat; WO $=$ whole oats; $\mathrm{WF}=$ wheat flour; $\mathrm{OF}=$ oat flour. The circles show the tube locations, and the triangles show the grain pile locations. A1 to $\mathrm{A5}$ indicate the areas with a similar airflow rate.

\section{Preparation of grain tubes and piles}

Grain or flour were placed inside short metal tubes $(0.35 \mathrm{~m}$ diameter and $0.15 \mathrm{~m}$ high) or were freely poured on the concrete floor of the building (Fig. 1). The vials with 50 adults were inserted in the middle of each tube or pile (Fig. 1). Six thermocouples were installed inside each tube. Thermocouples were located at the bottom, middle and top of the centre and wall of the tubes. The thermocouple located at the bottom of the tubes was taped on the concrete floor. There were three thermocouples located inside each grain or flour pile (Fig. 1). The thermocouples were connected to a data acquisition system (Agilent Technologies, Inc., Santa Clara, CA) and the temperatures were recorded every $2 \mathrm{~min}$.

\section{Experimental procedure}

Grain or flour was placed into the tubes or on the concrete floor through a funnel. The bottom diameters of the pile of whole wheat, whole oats, wheat flour, and oat flour were $0.603 \pm 0.02 ; 0.580 \pm 0.02 ; 0.463 \pm 0.01 ;$ and $0.493 \pm 0.01 \mathrm{~m}$, respectively. Twelve grain tubes and 12 grain piles were arranged in two concentric circles (Fig. 2). The grain tubes were located in the inner circle $(2.0 \mathrm{~m}$ diameter) and the piles in the outer circle with $2.2 \mathrm{~m}$ diameter. Based on the airflow distribution, the experimental area was subdivided into six areas and the airflow rate in each area was in the range of $\pm 0.3 \mathrm{~m} / \mathrm{s}$ (Fig. 2).

The building $(2.75 \times 18 \times 18 \mathrm{~m})$ was metal clad and had a $0.46 \mathrm{~m}$ concrete pad. There were 16 hopper- 


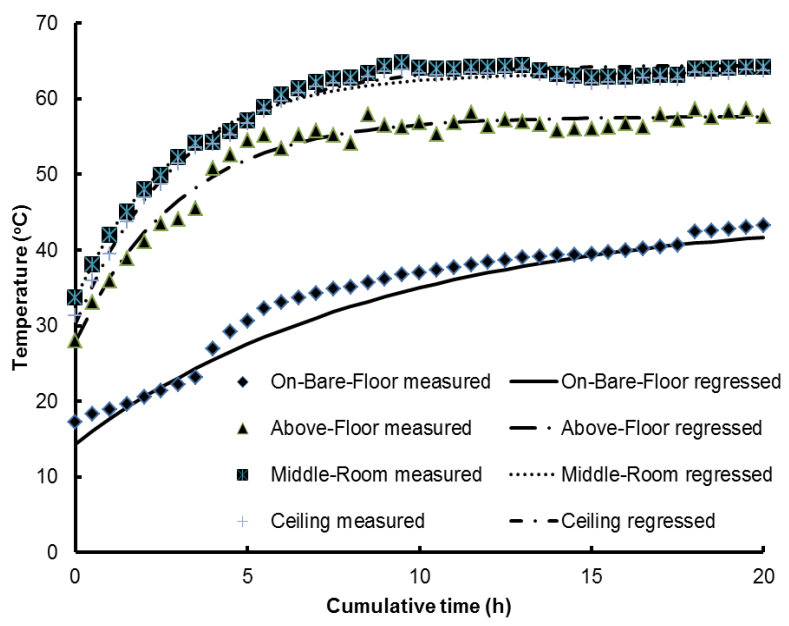

Fig. 3. Measured and regressed temperatures at the South-West location (coldest) of the experimental area inside the building undergoing heat treatment.

bottomed bins, $12.2 \mathrm{~m}$ height (including $1.8 \mathrm{~m}$ of the bottom part of the hopper) and 3.7 or $4.9 \mathrm{~m}$ diameter. Most of the bins were empty, but a few contained grain or grain products. The top and bottom of the bins were closed during the heat treatment process. The experiment was conducted at the southwest corner of the floor of the building (Fig. 2). To measure the temperature distribution in both vertical and horizontal directions, temperatures at four corners of the experimental location were measured (Fig. 2). At each location, thermocouples were located at the top (about $0.5 \mathrm{~m}$ below the ceiling, referred to as Ceiling), middle ( $9 \mathrm{~m}$ above the floor, referred to as Middle-Room), bottom (about $0.05 \mathrm{~m}$ above the floor, referred to as Above-Floor), and on the concrete floor of the building (referred to as On-Bare-Floor). From 10:00 $\mathrm{AM}$ to 8:00 AM the next day, the building was heattreated using a heater (Temp-Air, Model: Temp-Heat THP-4500, Burnsville, MN, USA). The heater produced between 200,000 to $4,500,000 \mathrm{BTU} / \mathrm{h} \quad(58600$ to $1,318,800 \mathrm{~W}$ ) with airflow of $0.71 \mathrm{~m}^{3} / \mathrm{min}$ (Johnson and Danley 2003).

The temperatures took about $12 \mathrm{~h}$ to reach maximum temperature of $64.5^{\circ} \mathrm{C}$ at the ceiling. The heating rate was about $3.8^{\circ} \mathrm{C} / \mathrm{h}$. To generate an evenly distributed temperature, four circulating fans $(1.20 \mathrm{~m}$ diameter and $0.60 \mathrm{~m}$ wide, VS-36, Schaefer, Florida, USA) were used on each floor, and were occasionally adjusted.

After a $20 \mathrm{~h}$ heat treatment, when the heaters were shut down and the temperature at the centre of the grain mass inside the tubes or piles was cooled down to $\leq 45^{\circ} \mathrm{C}$, the grain was sampled at the centre location of the grain mass and its moisture content determined (ASABE 2009). The mortality of adults inside the vials was visually determined in the laboratory at room temperature.

\section{Data analysis}

Non-linear regression was conducted to fit the measured temperatures (Sigmaplot 2010). The equation of Exponential Rise to Maximum (Eq. 1) had the high $\mathrm{R}^{2}$ values with a minimum of 0.94 for the measured temperatures of room and grains in all of the replicates (Table 1, Fig. 3). Therefore, this equation (Eq.1) was used to characterize the measured temperatures.

$$
T=T_{0}+a\left(1-e^{-b t}\right)
$$

where:

$$
\mathrm{T}=\text { temperature }\left({ }^{\circ} \mathrm{C}\right) \text {, }
$$

\begin{tabular}{|c|c|c|c|c|c|}
\hline \multirow{2}{*}{\multicolumn{2}{|c|}{ Location $^{[\mathrm{a}]}$}} & \multicolumn{3}{|c|}{ Parameters ${ }^{[\mathrm{b}]}$} & \multirow{2}{*}{$\mathrm{R}^{2}$} \\
\hline & & $\mathrm{T}_{0}$ & $\mathrm{a}$ & $\mathrm{b}$ & \\
\hline \multirow{4}{*}{ Ceiling } & South-East & $33.4 \pm 0.2$ & $30.0 \pm 0.2$ & $0.335 \pm 0.003$ & 0.99 \\
\hline & North-East & $33.1 \pm 0.2$ & $31.2 \pm 0.2$ & $0.328 \pm 0.004$ & 0.99 \\
\hline & North-West & $30.9 \pm 0.2$ & $32.9 \pm 0.2$ & $0.329 \pm 0.004$ & 0.98 \\
\hline & South-West & $33.7 \pm 0.2$ & $29.8 \pm 0.2$ & $0.332 \pm 0.004$ & 0.99 \\
\hline \multirow{4}{*}{ Middle-Room } & South-East & $29.4 \pm 0.1$ & $33.7 \pm 0.2$ & $0.333 \pm 0.003$ & 0.99 \\
\hline & North-East & $30.3 \pm 0.2$ & $33.3 \pm 0.2$ & $0.341 \pm 0.003$ & 0.99 \\
\hline & North-West & $29.4 \pm 0.2$ & $34.5 \pm 0.2$ & $0.327 \pm 0.003$ & 0.99 \\
\hline & South-West & $30.3 \pm 0.2$ & $34.2 \pm 0.1$ & $0.326 \pm 0.003$ & 0.99 \\
\hline \multirow{4}{*}{ Above-Floor } & South-East & $27.9 \pm 0.2$ & $29.7 \pm 0.2$ & $0.332 \pm 0.005$ & 0.97 \\
\hline & North-East & $22.0 \pm 0.5$ & $43.6 \pm 0.5$ & $0.294 \pm 0.006$ & 0.95 \\
\hline & North-West & $22.8 \pm 0.3$ & $28.0 \pm 0.3$ & $0.424 \pm 0.007$ & 0.96 \\
\hline & South-West & $27.9 \pm 0.2$ & $29.7 \pm 0.2$ & $0.332 \pm 0.005$ & 0.97 \\
\hline \multirow{4}{*}{ On-Bare-Floor } & South-East & $12.1 \pm 0.2$ & $37.0 \pm 0.2$ & $0.119 \pm 0.002$ & 0.98 \\
\hline & North-East & $14.6 \pm 0.2$ & $40.6 \pm 0.2$ & $0.151 \pm 0.003$ & 0.98 \\
\hline & North-West & $14.0 \pm 0.5$ & $27.6 \pm 0.5$ & $0.248 \pm 0.009$ & 0.95 \\
\hline & South-West & $14.4 \pm 0.1$ & $30.5 \pm 0.2$ & $0.113 \pm 0.002$ & 0.99 \\
\hline
\end{tabular}

Table 1. Regression parameters of the measured room temperatures.

\footnotetext{
[a] The location is in the order of from the hottest to the coldest.

${ }^{[b]}$ Parameters for the regression equation $T=T_{0}+a\left(1-e^{-b t}\right)$.
} 


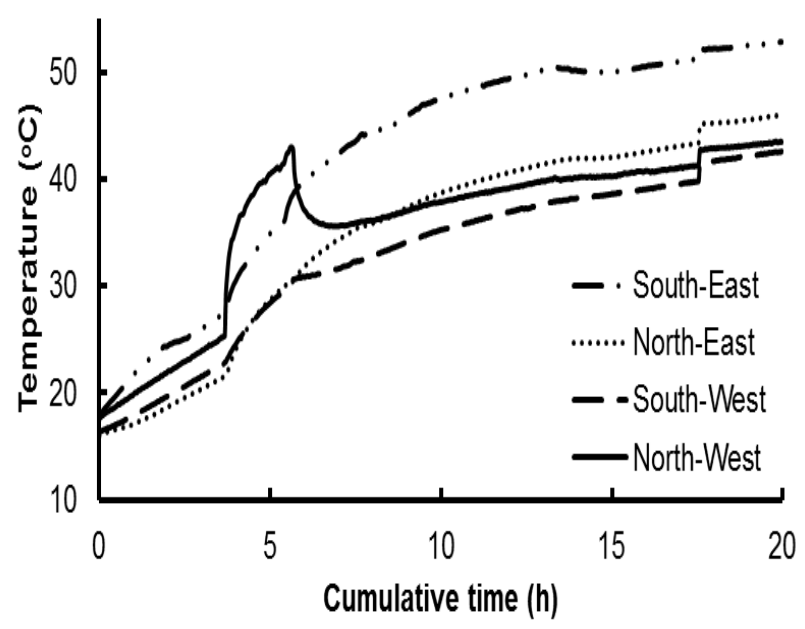

Fig. 4. Temperatures of On-Bare-Floor at the locations of Southeast, Northeast, Southwest, and Northwest. The rapid rise in temperature at $4 \mathrm{~h}$ at the Northwest location was due to repositioning circulating fans.

$\mathrm{T}_{0}, \mathrm{a}$, and $\mathrm{b}=$ constants, and

$\mathrm{t}=$ the cumulative time of the heat treatment $(\mathrm{h})$.

The rate of temperature increase is the slope (derivative) of Eq.1:

$$
\begin{aligned}
& T^{\prime}=a b e^{-b t} \\
& \lim _{t \rightarrow 20} e^{-b t}=0
\end{aligned}
$$

where:

$\mathrm{T}^{\prime}=$ the rate of temperature increase $\left({ }^{\circ} \mathrm{C} / \mathrm{h}\right) ; 20 \mathrm{~h}$ is the maximum time of heat treatment.

The temperature would reach $97 \%$ of the maximum temperature in each replicate when $t=\frac{-\ln 0.03}{b}$. Equation 2 at $t_{h}=\frac{-\ln 0.03}{2 b}$ was used to calculate the rate of temperature increase (mathematically, the slope at $t_{h}$ was close to the average rate of the temperature increase). The measured temperatures at $t \geq \frac{-\ln 0.03}{b}$ were designated as the measured maximum temperatures (MT). If $\frac{-\ln 0.03}{b} \geq$ 20 , the measured temperature at $t=20 \mathrm{~h}$ of the cumulative time of the heat treatment was designated as the MT. The calculated value of $-\ln 0.03 / \mathrm{b}$ was the time at which the temperature reached $97 \%$ of its maximum temperature $(\mathrm{h})$.

To evaluate the room temperature variations, the following statistics were calculated: 1) means and standard errors of the temperatures at the same height and same cumulative time of the heat treatment; 2) the temperature difference at the same heights and at the same cumulative time of the heat treatment but at different locations (TD).

If grain at the surface of the tubes or piles experienced the process of thin layer drying, the drying rate of the thin layer would increase with increasing air temperature, but would be independent of airflow rate (Bala 1997). However, different airflow would create different vicinity temperatures. Therefore, it was hypothesized that the surface temperature of the grains inside the tubes or piles was mainly influenced by the vicinity temperature, periphery configuration (flat or sloped surface in tubes or piles, respectively), grain type, and grain moisture content.

In this study, there are not enough data to verify the effect of moisture content and grain type. To verify the influences of periphery configurations, a two-factor experiment was designed and factor analysis was conducted by comparing the rate of temperature increase and MT of the surface temperature of grains. During the factor analyses, one factor was the area in which the grains were located (Fig. 2) and the other was the periphery configuration (pile or tube).

Table 2. Time to reach the $97 \%$ maximum temperature, maximum temperature, and rate of temperature

\begin{tabular}{|c|c|c|c|c|}
\hline & Location $^{[a]}$ & Time $(\mathrm{h})^{[\mathrm{b}]}$ & MT $\left({ }^{\circ} \mathrm{C}\right)^{[\mathrm{c}]}$ & Rate $\left({ }^{\circ} \mathrm{C} / \mathrm{h}\right)^{[\mathrm{d}]}$ \\
\hline \multirow{4}{*}{$\begin{array}{l}\text { Inside the heat-treated } \\
\text { building }\end{array}$} & Ceiling & $10.59 \pm 0.05 \mathrm{Z}$ & $63.2 \pm 0.0 \mathrm{Z}$ & $1.8 \pm 0.0 \mathrm{Z}$ \\
\hline & Middle-Room & $10.50 \pm 0.22 \mathrm{Z}$ & $63.1 \pm 0.0 \mathrm{Z}$ & $2.0 \pm 0.0 \mathrm{Z}$ \\
\hline & Above-Floor & $10.60 \pm 0.83 \mathrm{Z}$ & $57.4 \pm 0.1 \mathrm{Z}$ & $1.9 \pm 0.1 \mathrm{Z}$ \\
\hline & On-Bare-Floor & $24.50 \pm 3.85 \mathrm{Y}$ & $46.2 \pm 2.3 \mathrm{Y}$ & $0.9 \pm 0.1 \mathrm{Y}$ \\
\hline \multirow{4}{*}{ On-Bare-Floor } & South-East & 23.25 & 52.8 & 1.1 \\
\hline & North-East & 29.47 & 46.0 & 0.8 \\
\hline & North-West & 14.15 & 43.5 & 1.2 \\
\hline & South-West & 31.14 & 42.6 & 0.6 \\
\hline \multicolumn{5}{|c|}{$\begin{array}{l}{[\mathrm{a}] \text { Location is in the order of from the top to bottom inside the building, or from hottest to the coldest on the bare concrete floor. }} \\
\text { [b] Time to reach } 97 \% \text { maximum temperature. } \\
\text { [c] Maximum temperature. } \\
\text { [d] Rate of the temperature increase. } \\
\text { In the columns of Time, MT, and Rate, the different letters ( } \mathrm{Z} \text { and } \mathrm{Y}) \text { after the number indicted significantly difference at } 0.05 \text { level } \\
\text { using Tukey test. }\end{array}$} \\
\hline
\end{tabular}
increase inside the heat-treated building and on the bare concrete floor. 
Table 3. Mean and the maximum of the standard errors of the measured room temperatures at different locations.

\begin{tabular}{|c|c|c|c|}
\hline \multirow[t]{2}{*}{ Location } & \multicolumn{2}{|c|}{ Standard errors $\left({ }^{\circ} \mathrm{C}\right)$} & \multirow[t]{2}{*}{$\operatorname{MTD}^{[\mathrm{a}]}\left({ }^{\circ} \mathrm{C}\right)$} \\
\hline & $\begin{array}{c}\text { Mean } \pm \\
\text { SE }\end{array}$ & Maximum & \\
\hline Ceiling & $0.2 \pm 0.0$ & 0.7 & 2.6 \\
\hline Middle-Room & $0.2 \pm 0.0$ & 1.3 & 2.7 \\
\hline Above-Floor & $2.2 \pm 0.0$ & 3.4 & 16.5 \\
\hline On-Bare-Floor & $2.1 \pm 0.0$ & 3.1 & 12.7 \\
\hline
\end{tabular}

[a] MTD = the maximum of the temperature difference at the same heights and at the same cumulative time of the heat treatment but at different locations.

\section{RESULTS AND DISCUSSION}

\section{Room temperature distribution}

Inside the heat-treated building, the temperature at the measured location, except On-Bare-Floor, reached their maximum temperatures at the end of the heat treatment (Table 2, Fig. 3). Compared with the temperatures at other locations, the temperatures under Ceiling had higher initial temperatures (more than $3{ }^{\circ} \mathrm{C}$ higher than at Middle-Room, Fig. 3). This was the reason why the Ceiling had a lower mean rate of temperature increase than that at MiddleRoom and Above-Floor. There was no significant difference in the rate of temperature increase, in reaching 97\% maximum temperature, or maximum temperature among Ceiling, Middle-Room and Above-Floor. However, there was a significant difference between the On-BareFloor and temperatures at other locations (Table 2). These results indicated that the temperature gradients in the vertical direction decreased with the increase of height, even though some places on the floor had circulating fans. The mean and maximum temperature differences between the locations, Middle-Room and Above-Floor, were $5.2 \pm 0.1^{\circ} \mathrm{C}$ and $9.4^{\circ} \mathrm{C}$, while those at Above-Floor and OnBare-floor were $18.1 \pm 0.2^{\circ} \mathrm{C}$ and $26.9^{\circ} \mathrm{C}$, respectively (Fig. 3). This created a maximum of $5.4^{\circ} \mathrm{C} / \mathrm{cm}$ and a mean of $3.6 \pm 0.0^{\circ} \mathrm{C} / \mathrm{cm}$ temperature gradients above the surface of the concrete floor without grain. Therefore, to kill all insects inside a building, the temperature on the concrete floor during heat treatment should be closely monitored.

The standard errors of the temperatures at AboveFloor and On-Bare-Floor were the first and second largest, compared to those at Middle-Room and Ceiling (Table 3). The maximum value of the TD at Ceiling was $2.6^{\circ} \mathrm{C}$ and the lowest temperature did not always occur at one location. The maximum value of the temperature differences at Above-Floor and On-Bare-Floor were 16.5 and $12.7^{\circ} \mathrm{C}$, respectively (Table 3). The lowest temperature at Above-Floor and On-Bare-Floor always occurred at the South-West location (Fig. 4). Temperature at Ceiling was higher than that at Middle-Room in the first $2.6 \mathrm{~h}$ of the cumulative heat treatment time (Fig. 3). After $2.6 \mathrm{~h}$ and before the heaters were shut down, there was no significant difference at these two locations (Fig. 3, Table 2 , Paired T-test, $\mathrm{t}=1.86, \mathrm{P}=0.06$ ). The temperature of On-Bare-Floor was always lower than that at the higher locations. These results, therefore, indicated the following: 1) room temperature at different locations had the same distribution pattern in the vertical direction, even though some places had circulating fans; 2) temperatures at lower locations had larger variations than those at higher locations; and 3) temperatures of On-Bare-Floor had the largest temperature variation.

Table 4. Effect of vicinity temperature and periphery configuration on the surface temperature of the grain mass.

\begin{tabular}{|c|c|c|c|c|c|}
\hline \multirow[t]{2}{*}{ Comparison } & \multirow[t]{2}{*}{ Source } & \multicolumn{2}{|c|}{ Rate $^{[\mathrm{a}]}$} & \multicolumn{2}{|c|}{$\mathrm{MT}^{[\mathrm{b}]}$} \\
\hline & & $\mathrm{F}^{[\mathrm{c}]}$ & $\mathrm{P}^{[\mathrm{c}]}$ & $\mathrm{F}^{[\mathrm{c}]}$ & $\mathrm{P}^{[\mathrm{c}]}$ \\
\hline \multirow{3}{*}{$W W^{[d]}$ in tube $-W W$ in pile } & Location $^{[\mathrm{e}]}$ & 0.05 & 0.8639 & 3121.25 & $<0.0001$ \\
\hline & Configuration ${ }^{[\mathrm{f}]}$ & 0.24 & 0.7109 & 49.46 & $<0.0001$ \\
\hline & Interaction $^{[\mathrm{g}]}$ & 0.94 & 0.5096 & 8.23 & $<0.0042$ \\
\hline \multirow{3}{*}{$\mathrm{WO}$ in tube - WO in pile } & Location $^{[\mathrm{e}]}$ & 0.18 & 0.7122 & 832.77 & $<0.0001$ \\
\hline & Configuration ${ }^{[\mathrm{f}]}$ & 0.02 & 0.8971 & 3112.21 & $<0.0001$ \\
\hline & Interaction $^{[\mathrm{g}]}$ & 0.16 & 0.7273 & 257.35 & $<0.0001$ \\
\hline \multirow{3}{*}{$\mathrm{WF}$ in tube $-\mathrm{WF}$ in pile } & Location $^{[\mathrm{e}]}$ & 0.73 & 0.4840 & 31.51 & $<0.0001$ \\
\hline & Configuration $^{[\mathrm{f}]}$ & 0.27 & 0.6553 & 4.58 & 0.0329 \\
\hline & Interaction $^{[\mathrm{g}]}$ & 23.91 & 0.0394 & 121.40 & $<0.0001$ \\
\hline \multirow{3}{*}{ OF in tube - OF in pile } & Location $^{[\mathrm{e}]}$ & 66.02 & 0.0148 & 164.96 & $<0.0001$ \\
\hline & Configuration ${ }^{[\mathrm{f}]}$ & 17.57 & 0.0525 & 5822.14 & $<0.0001$ \\
\hline & Interaction ${ }^{[\mathrm{g}]}$ & 0.10 & 0.7769 & 12.58 & 0.0004 \\
\hline \multicolumn{6}{|c|}{$\begin{array}{l}{[\mathrm{a}] \text { Rate of temperature increase. }} \\
{ }^{\mathrm{b}]} \text { Maximum temperatures. } \\
{ }^{\mathrm{cc}]} \mathrm{F} \text { and } \mathrm{P} \text { values of the factor test. } \\
{ }^{\mathrm{d}]} \mathrm{WW}=\text { whole wheat; } \mathrm{WO}=\text { whole oats; } \mathrm{WF}=\text { wheat flour; } \mathrm{OF}=\text { oat flour. } \\
{ }^{\mathrm{e}]} \text { Effect of the vicinity temperature. } \\
{ }^{\mathrm{f}]} \text { Periphery configuration (tube or pile). } \\
{ }^{\mathrm{g}]} \text { Interaction effect of the vicinity temperature and the tested factor. }\end{array}$} \\
\hline
\end{tabular}


Table 5. Time to reach $97 \%$ maximum temperature, rate of temperature increase, and maximum temperature of the grains

\begin{tabular}{|c|c|c|c|c|c|c|c|}
\hline \multirow{2}{*}{$\begin{array}{l}\text { Grain } \\
\text { type }\end{array}$} & \multirow[t]{2}{*}{ Location } & \multicolumn{2}{|c|}{ Time $(\mathrm{h})^{[\mathrm{a}]}$} & \multicolumn{2}{|c|}{ Rate $\left({ }^{\circ} \mathrm{C} / \mathrm{h}\right)^{[\mathrm{b}]}$} & \multicolumn{2}{|c|}{$\mathrm{MT}\left({ }^{\circ} \mathrm{C}\right){ }^{[\mathrm{c}]}$} \\
\hline & & Tube & Pile & Tube & Pile & Tube & Pile \\
\hline \multirow{3}{*}{ Wheat } & Surface & $13.0 \pm 0.3$ & $14.6 \pm 2.5$ & $1.7 \pm 0.2 \mathrm{Z}$ & $1.5 \pm 0.2 \mathrm{Z}$ & $56.8 \pm 0.1 \mathrm{Z}$ & $56.9 \pm 0.1 \mathrm{Z}$ \\
\hline & Middle & $63.6 \pm 3.10$ & $36.5 \pm 7.4$ व & $0.5 \pm 0.0 \mathrm{Y}$ & $0.7 \pm 0.1 \mathrm{Y}$ & $45.6 \pm 0.3 \mathrm{Y}$ & $48.1 \pm 1.7 \mathrm{Y}$ \\
\hline & On floor & ס $265103.9 \pm 146686.1$ & ס335241.5 & $0.2 \pm 0.0 \mathrm{X}$ & $0.2 \pm 0.0 \mathrm{X}$ & $36.8 \pm 0.1 \mathrm{X}$ & $33.0 \pm 0.2 \mathrm{X}$ \\
\hline \multirow{3}{*}{ Oats } & Surface & $12.0 \pm 0.6$ & $11.5 \pm 0.5$ & $2.0 \pm 0.1 \mathrm{Z}$ & $2.0 \pm 0.1 \mathrm{Z}$ & $56.5 \pm 0.1 \mathrm{Z}$ & $59.4 \pm 0.1 \mathrm{Z}$ \\
\hline & Middle & $34.2 \pm 2.20$ & $24.5 \pm 10$ & $0.6 \pm 0.0 \mathrm{Y}$ & $0.8 \pm 0.0 \mathrm{Y}$ & $43.6 \pm 0.3 \mathrm{Y}$ & $46.9 \pm 1.0 \mathrm{Y}$ \\
\hline & On floor & $11173.5 \pm 1007.20$ & $281557.7 \pm 280388.90$ & $0.2 \pm 0.0 \mathrm{X}$ & $0.2 \pm 0.0 \mathrm{X}$ & $35.2 \pm 0.2 \mathrm{X}$ & $32.9 \pm 0.6 \mathrm{X}$ \\
\hline \multirow{3}{*}{$\begin{array}{l}\text { Wheat } \\
\text { flour }\end{array}$} & Surface & $21.5 \pm 4.4$ ○ & $20.5 \pm 3.20$ & $1.3 \pm 0.4 \mathrm{Z}$ & $1.4 \pm 0.3 \mathrm{Z}$ & $61.5 \pm 0.1 \mathrm{Z}$ & $60.9 \pm 0.2 \mathrm{Z}$ \\
\hline & Middle & $2254.3 \pm 1972.00$ & $52.9 \pm 13.00$ & $0.3 \pm 0.0 \mathrm{Y}$ & $0.5 \pm 0.1 \mathrm{Y}$ & $43.1 \pm 0.8 \mathrm{Y}$ & $42.7 \pm 1.1 \mathrm{Y}$ \\
\hline & On floor & $40878.3 \pm 755273.20$ & $681876.1 \pm 70207.6$ व & $0.2 \pm 0.0 \mathrm{X}$ & $0.2 \pm 0.0 \mathrm{X}$ & $38.4 \pm 0.3 \mathrm{X}$ & $37.2 \pm 0.6 \mathrm{X}$ \\
\hline \multirow{3}{*}{$\begin{array}{l}\text { Oat } \\
\text { flour }\end{array}$} & Surface & $22.8 \pm 4.20$ & $17.2 \pm 2.00$ & $1.3 \pm 0.3 \mathrm{Z}$ & $1.7 \pm 0.3 \mathrm{Z}$ & $61.5 \pm 0.1 \mathrm{Z}$ & $64.9 \pm 0.1 \mathrm{Z}$ \\
\hline & Middle & ס & $39.6 \pm 3.20$ & $0.4 \pm 0.0 \mathrm{Y}$ & $0.6 \pm 0.1 \mathrm{Y}$ & $46.2 \pm 0.5 \mathrm{Y}$ & $47.6 \pm 1.0 \mathrm{Y}$ \\
\hline & On floor & 740163.5土44617.60 & ه19739 & $0.2 \pm 0.0 \mathrm{X}$ & $0.2 \pm 0.0 \mathrm{X}$ & $39.5 \pm 0.2 \mathrm{X}$ & $38.9 \pm 0.6 \mathrm{X}$ \\
\hline
\end{tabular}

${ }^{[a]}$ Time to reach $97 \%$ maximum temperature.

${ }^{[b]}$ Rate of the temperature increase.

${ }^{[c]}$ Maximum temperature.

D At least one replicate in the treatment did not reach the $97 \%$ maximum temperature.

In the columns of Time, MT, and Rate, the different letters (X, Y and Z) after the number indicted significantly difference at 0.05

level using Tukey test.

Surface $=$ at the surface of the grain, Middle $=$ at the middle of the grain, Bottom $=$ at the bottom of the grain.

The Southwest location was consistently the coolest location and was located at the corner of the building (Table 2, Fig. 2). At different locations and above the floor, the air velocity created by circulating fans was different and varied from 3.7 to $6.7 \mathrm{~m} / \mathrm{s}$. The South-West corner also had the lowest airflow. It was proposed that different air flows on the floor caused different floor temperatures. Therefore, creating a uniform air flow on the floor of the entire building during the heat treatment period might be more important than creating certain airflows at higher locations. Uniform air flow on the floor might also help to avoid under-heated floor areas.

\section{Temperature on the surface of the grain mass}

The periphery configurations (flat or sloped surface in tubes or piles, respectively) did not significantly influence the increasing rate of the surface temperatures of the grain mass, while the vicinity temperature significantly influenced the rate of temperature increase in one of the factor tests (Table 4). Vicinity temperature and periphery configurations significantly influenced the MT of the surface temperatures of grain mass (Table 4). There were interactions between the vicinity temperature and periphery configuration. These results indicated that the vicinity temperature mainly influenced the rate of temperature increase at the grain surface. The heat treatment temperature and the airflow rate at the different locations mainly influenced the vicinity temperature. After the surface grain temperature reached $97 \%$ of its maximum temperature (which was close to the vicinity temperature) it was influenced by the periphery configurations. At the end of the heat treatment, these influences could make $1.8 \pm 0.8{ }^{\circ} \mathrm{C}$ difference between different configurations of the same grain at the same location.

\section{Temperature inside grain mass}

The temperature of the concrete floor with grain was always lower than that of the concrete floor without grain and that of grain at the surface or middle location (Fig. 4, Table 5). The rate of temperature increase at the middle or bottom of the grain mass was significantly lower than that at its higher location (Table 5). Grain inside the tubes or piles and at the middle or on the floor did not reach the maximum temperature at the end of the heat treatment (Table 5). These results indicate that increasing grain depth on the concrete floor would decrease the temperature on the concrete floor. These results were consistent with the heat transfer theory and the simulation results (Jian et al. 2012). The mean and maximum of temperature difference between the top and the bottom of the grain mass inside tubes or piles were $24.9 \pm 0.3^{\circ} \mathrm{C}$ and $36.2^{\circ} \mathrm{C}$, respectively. The mean and maximum values of temperature gradients inside all tubes and piles were $1.3 \pm 0.1^{\circ} \mathrm{C} / \mathrm{cm}$ and $2.4^{\circ} \mathrm{C} / \mathrm{cm}$, respectively. There was no insect mortality in any of the tubes or piles. These results were consistent with published works related to insect mortality under different temperatures (Fields 1992; Mahroof et al. 2003a; 2003b; Roesli et al. 2003). We would expect that insects would migrate from the hotter areas of the mill, equipment, and upper floors and seek refuge on the cooler concrete floor (Jian et al. 2002). Therefore, sanitation might be necessary if a certain thickness of grain was left on the floor. In Part II of this research, we studied the maximum amount of grain or grain products that can be left in equipment and on floors yet still allow enough heat to penetrate the product and control all insects (Jian et al. 2012). 


\section{CONCLUSIONS}

1) Room temperature at higher locations had a smaller variation than those at lower locations.

2) Room temperature at different locations had the same distribution pattern in the vertical direction, even though some places had circulating fans.

3) The temperature gradients in the vertical direction decreased with increasing height. The maximum and mean values of the temperature gradients above the surface of the concrete floor, without grain, were $5.4^{\circ} \mathrm{C} / \mathrm{cm}$ and $3.6 \pm 0.0^{\circ} \mathrm{C} / \mathrm{cm}$, respectively.

4) The vicinity temperature mainly influenced the rate of temperature increase at the grain surface. After the surface grain temperature reached $97 \%$ of its maximum temperature, the surface grain temperature would be influenced by the vicinity temperature and periphery configurations (flat or sloped surface in tubes or piles, respectively).

5) Increasing grain depth on the concrete floor decreased the temperature on the concrete floor.

\section{ACKNOWLEDGEMENT}

The authors thank Tannis Mayert (Agriculture and AgriFood Canada) and Duangsamorn Suthisut (Department of Agriculture, Thailand) for technical assistance.

\section{REFERENCES}

Akdogan, H., M.E. Casada, A.K. Dowdy and B. Subramanyam. 2005. A novel method for analyzing grain facility heat treatment data. Journal of Stored Products Research 41: 175-185.

ASABE. 2009. ASABE Standards S352.2 APR 1988 (R2008):Moisture measurement - unground grain and seeds. St. Joseph, MI: American Society of Agricultural and Biological Engineers.

Bala, B.K. 1997. Drying and Storage of Cereal Grains. Enfield, New Hampshire: Science Publishers, Inc.

Beckett, S.J., P.G. Fields and B. Subramanyam. 2007. Disinfestation of stored products and associated structures using heat. In Theory and Practice- Heat Treatments for Post Harvest Pest Control, eds. J. Tang, E. Mitcham, S. Wang and S. Lurie, 182-237. Oxfordshire and Cambridge, MA: CABI, Wallingford.

Dean, D.A. 1911. Heat as a means of controlling building insects. Journal of Economic Entomology 4: 142-158.

Fields, P.G. 1992. The control of stored-product insects and mites with extreme temperature. Journal of Stored Products Research 28: 89-118.
Fields, P.G. and N.D.G. White. 2001. Alternatives to methyl bromide treatments for stored-product and quarantine insects. Annual Review of Entomology 47: 331-359.

Imholte, T.J. and T. Imholte-Tauscher. 1999. Engineering for Food Safety and Sanitation. Woodinville, Washington DC: Technical Institute of Food Safety.

Jian, F., D.S. Jayas and N.D.G. White. 2002. Temperature and geotaxis preference by Cryptolestes ferrugineus (Coleoptera: Laemophloeidae) adults in response to $5^{\circ} \mathrm{C} / \mathrm{m}$ temperature gradients at optimum and hot temperatures in stored wheat and their mortality at high temperatures. Environmental Entomology 31: 816-826.

Jian, F., D.S. Jayas and N.D.G. White. 2009. Temperature fluctuations and moisture migration in wheat stored for 15 months in a metal silo in Canada. Journal of Stored Product Research 45: 82-90.

Jian, F., P.G. Fields, D.S. Jayas, N.D.G. White and M. Loganathan. 2012. Measured and predicted temperatures in a grain processing building under heat treatment -2 . Mathematical modeling of heat and mass transfer during heat treatment. Canadian Biosystems Engineering 54: 3.9-3.17.

Johnson, R.D. and T.T. Danley. 2003. Pest control system. USA patent $6,588,140 \mathrm{~B} 1$.

Mahroof, R., B. Subrammanyam, J.E. Throne and A. Menon. 2003a. Time-mortality relationships for Tribolium castaneum (Coleoptera: Tenebrionidae) life stages exposed to elevated temperatures. Journal of Economic Entomology 96: 1344-1351.

Mahroof, R., B. Subrammanyam, J.E. Throne and A. Menon. 2003b. Temperature and relative humidity profiles during heat treatment of buildings and its efficacy against Tribolium castaneum (Herbst) life stages. Journal of Stored Products Research 39: 555569.

Roesli, R., B. Subramanyam, F.J. Fairchild and K. Behnke. 2003. Trap catches of stored-product insects before and after heat treatment in a pilot feed building. Journal of Stored Products Research 39: 521-540.

SigmaPlot. 2010. SigmaPlot 11.2 Analyze and Graph Your Data with Unparallelled Ease and Precision, User's Guide. Chicago IL: Systat Software Inc. 